\title{
The invasive Chinese mystery snail Bellamya chinensis (Gastropoda: Viviparidae) expands its European range to Belgium
}

\author{
Tom Van den Neucker ${ }^{1, *}$, Tom Schildermans ${ }^{2}$ and Kevin Scheers ${ }^{3}$ \\ ${ }^{1}$ University of Antwerp, Department of Biology, Ecosystem Management Research Group, Universiteitsplein 1C, 2160 Wilrijk, Belgium \\ 2 Weidestraat 11, 2490 Balen, Belgium \\ ${ }^{3}$ Research Institute for Nature and Forest (INBO), Kliniekstraat 25, 1070 Brussels, Belgium
}

\begin{abstract}
In this paper we report the first Belgian records of the invasive Chinese mystery snail Bellamya chinensis. A walkover-survey along the Laak, a small lowland river, yielded a total of 20 live B. chinensis. The presence of both juvenile and adult individuals, with a shell height ranging from 16.6 to $47.5 \mathrm{~mm}$, indicates that the species is firmly established. The most probable source of introduction is a nearby garden center that specializes in ornamental fish and plants for garden ponds.
\end{abstract}

Keywords: Bellamya chinensis / invasive species / Belgium

Résumé - L'escargot vivipare envahissant Bellamya chinensis (Gastropoda : Viviparidae) étend sa répartition européenne à la Belgique. Dans cet article, nous rapportons les premiers enregistrements belges de l'escargot vivipare invasif Bellamya chinensis. Une prospection le long du Laak, une petite rivière de plaine, a récolté un total de 20 B. chinensis vivants. La présence d'individus juvéniles et adultes, avec une hauteur de coquille allant de 16,6 à $47,5 \mathrm{~mm}$, indique que l'espèce est solidement établie. La source d'introduction la plus probable est un centre de jardinerie voisin qui se spécialise dans les poissons d'ornement et les plantes pour les mares de jardin.

Mots clés : Bellamya chinensis / espèce envahissante / Belgique

Bellamya chinensis (Gray, 1834), often referred to as Cipangopaludina chinensis (but see Smith, 2000), is a large freshwater snail, with a maximum shell height of $70 \mathrm{~mm}$ (Soes et al., 2011). The species occurs in a wide variety of waterbodies, including ponds, lakes, ditches, canals and slow flowing parts of rivers (Jokinen, 1982; McCann, 2014; Soes et al., 2016). The species prefers silt or sand substrates and water with dissolved calcium levels above 5 ppm (Jokinen, 1982). B. chinensis tolerates a wide range of water temperatures, from near freezing up to $30^{\circ} \mathrm{C}$ (Karatayev et al., 2009). It feeds mainly on epiphytic and benthic algae (Jokinen, 1982) and is also capable of filter-feeding (Olden et al., 2013). Female $B$. chinensis live up to five years and males three to four years (Jokinen, 1982). Stephen et al. (2013) estimate that female $B$. chinensis produce about 30 young per year. $B$. chinensis originates from SE Asia. Its native range includes China, Taiwan, Korea and Japan, although there are doubts about the taxonomic status of several subspecies described from these areas (Jokinen, 1982; Soes et al., 2016). The species also occurs outside its natural range. It was introduced into North America in the early 1890 s and is now a widespread

\footnotetext{
* Corresponding author: tom.vandenneucker@gmail.com
}

invasive alien species, with firmly established populations throughout the USA and in the SE of Canada (Jokinen, 1982; McAlpine et al., 2016). Recently, European non-indigenous populations of $B$. chinensis have been found in The Netherlands (Soes et al., 2011, 2016). In this paper we report the first Belgian records of $B$. chinensis and provide clues about the viability of the population and its possible origins.

On 5th May 2016, three freshly dead B. chinensis were found near the source of the river Laak in Balen, Belgium (N 51 ${ }^{\circ} 8^{\prime} 51.8^{\prime \prime}$; E 5 $8^{\prime} 1.9^{\prime \prime}$ ). The largest shell measured $60 \mathrm{~mm}$ in height. The specimens were found among sediment and riparian vegetation deposited on the bank of the river after mechanical cleaning. The Laak is a small lowland river with a total length of $1800 \mathrm{~m}$. It is a tributary of the river Grote Nete (Fig. 1). During spring and summer the river Laak is about $1 \mathrm{~m}$ wide and water depth rarely exceeds $30 \mathrm{~cm}$. The river bed consists mainly of silt, sand, sandstone and organic detritus. Stream velocity is low, almost stagnant in most parts of the river. Aquatic vegetation is nearly absent, because the river is heavily shaded by trees or tall riparian herbs along most of its course.

On 16th July 2016, walk-over surveys were carried out along the river Laak in an effort to collect living $B$. chinensis 


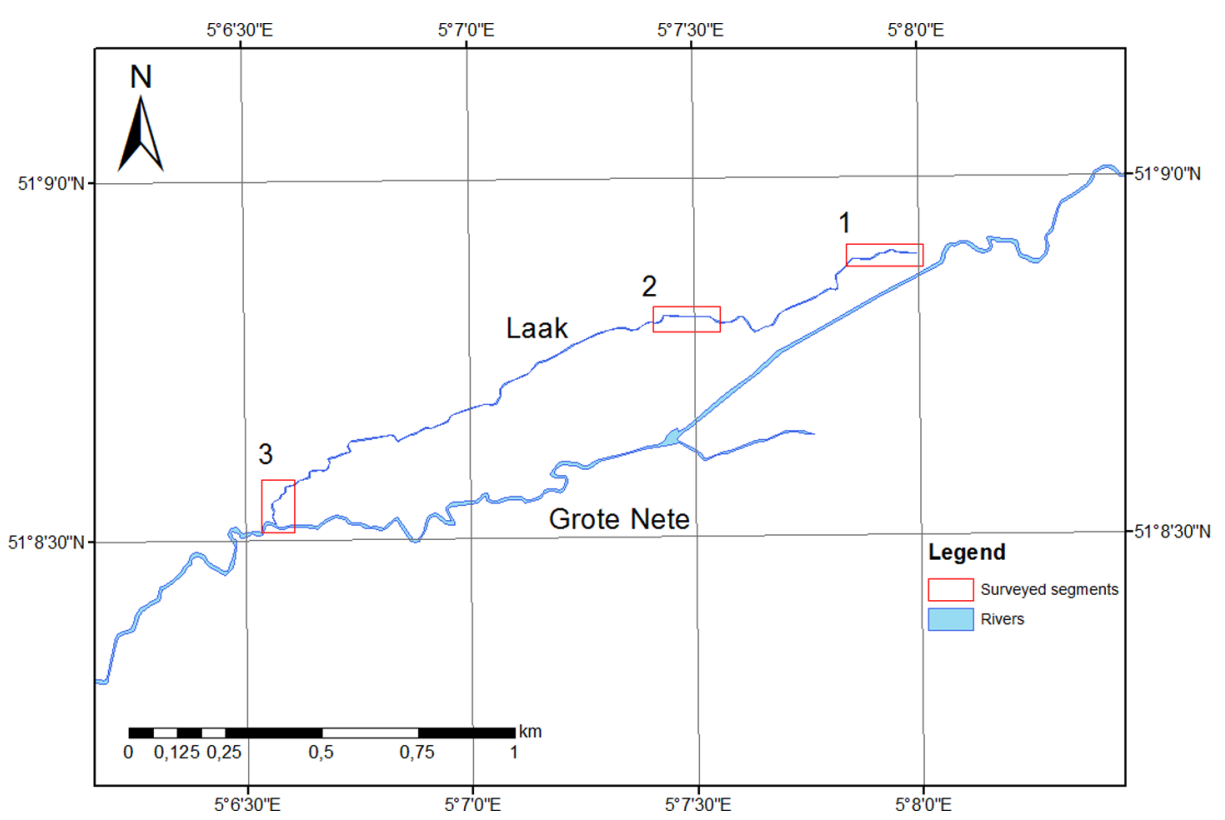

Fig. 1. Surveyed river segments along the river Laak (Balen, Belgium).

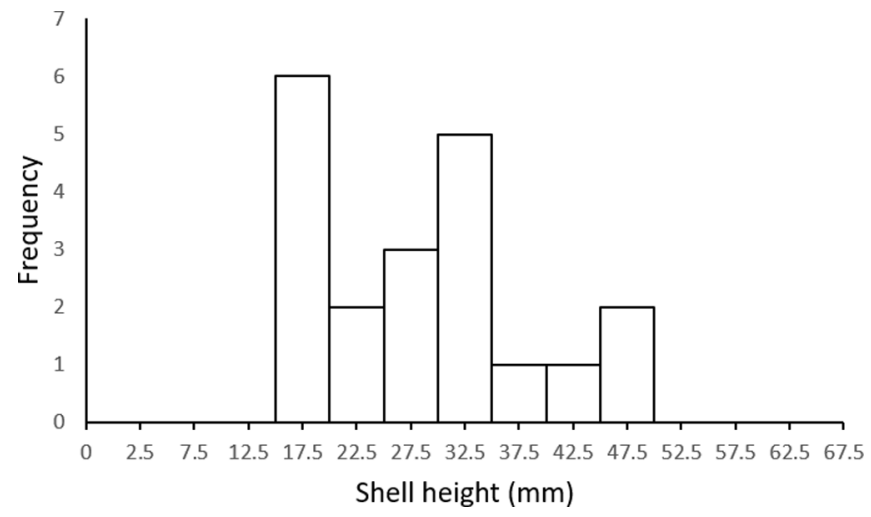

Fig. 2. Frequency distribution of shell height measurements of living B. chinensis collected in the river Laak $(N=20)$ on 16th July 2016. Shell height was measured to the nearest $0.1 \mathrm{~mm}$ with a Vernier micro calliper.

and to assess whether a viable population had established. Surveys were carried out along three $100 \mathrm{~m}$ river segments: near the source of the river, in the middle section and at the river mouth (Fig. 1). Murky water made it impossible to carry out a visual search in the main stem of the Grote Nete. The surveys along the Laak yielded a total of 20 living specimens: one snail was found near the source of the river, 18 were collected in the middle section and one near the river mouth. Both juvenile and adult $B$. chinensis were found, with a shell height ranging from 16.6 to $47.5 \mathrm{~mm}$ (Fig. 2).

The number of specimens collected during our search may not reflect the real density of $B$. chinensis in the river Laak. Visibility was limited because of murky water near the source and intense shading by trees in the downstream stretches. Consequently, several snails may have been overlooked during the survey. Still, the wide range of shell sizes indicates that the Laak harbours an established B. chinensis population, capable of sustaining itself through natural reproduction.

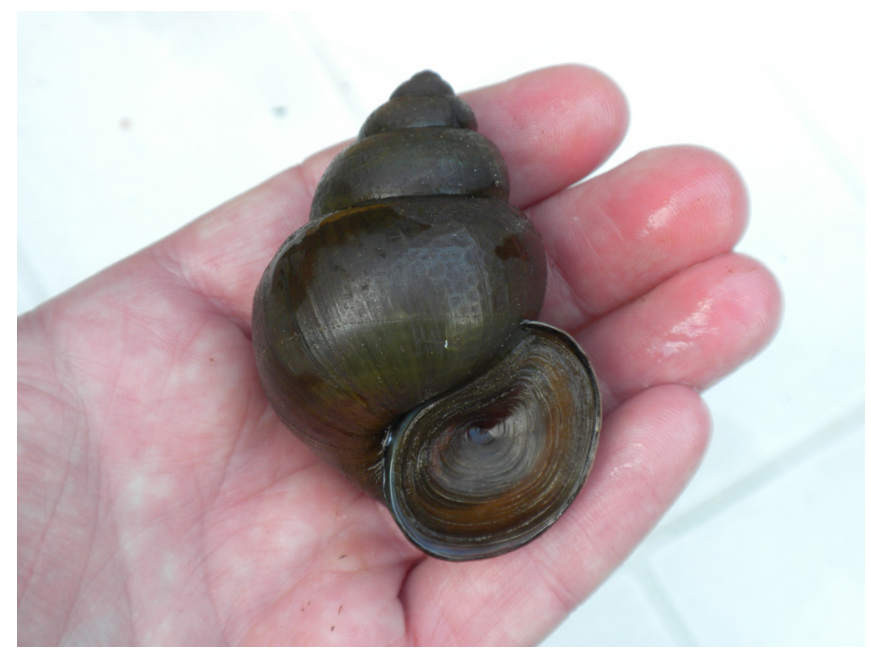

Fig. 3. An adult specimen of $B$. chinensis (shell height $60.6 \mathrm{~mm}$ ) offered for sale in a garden center near the river Laak (Balen, Belgium).

The most probable source of introduction is a nearby garden center that specializes in ornamental fish and plants for garden ponds. Large quantities of $B$. chinensis were offered for sale in the garden center at a price of 1.25 euro a piece (Fig. 3). Moreover, a series of rearing and stocking ponds owned by the garden center are situated next to the Laak. Therefore, $B$. chinensis may have been unintentionally introduced into the Laak during maintenance of the ponds and aquaria.

Its presence in the river Laak and its availability in garden centers may facilitate colonization of other lowland rivers in Belgium. Most Belgian lowland rivers have muddy river beds and slow currents, which fits the habitat preference of B. chinensis described in literature (Jokinen, 1982; McCann, 2014; Soes et al., 2016). The aquarium and ornamental trade has contributed significantly to the spread 
of other non-native aquatic invertebrates in Belgium (Boets et al., 2016) and is considered the most likely introduction pathway of $B$. chinensis in The Netherlands (Soes et al., 2011, 2016). The current widespread distribution in North America likely results from several independent unintentional introductions. The aquarium and ornamental trade are also considered important vectors in North America, but recreational activities such as boating are suspected to contribute to its further spread (Jokinen, 1982; Karatayev et al., 2009; Havel, 2011).

There are concerns that $B$. chinensis could have adverse effects on native fauna and flora (Karatayev et al., 2009). So far, only a few studies have addressed this issue. One possible concern is that $B$. chinensis may serve as an intermediate host for parasites. However, introduction of non-native parasites associated with $B$. chinensis is considered unlikely (Soes et al., 2011). Also, the capability of $B$. chinensis to serve as a vector for native parasitic trematodes may be limited (Harried et al., 2015). Other studies have focussed on potential negative impacts on native snail species (Johnson et al., 2009; Solomon et al., 2010). Solomon et al. (2010) found no impacts on native snail assemblages in a lake in Wisconsin (USA), although some native snails did not occur at sites where $B$. chinensis was abundant. This may suggest that $B$. chinensis is a rather benign invasive species. However, laboratory experiments showed that $B$. chinensis may alter algal biomass and nutrient cycling (Johnson et al., 2009). Other experiments showed that the filter-feeding capacity of $B$. chinensis is comparable to that of invasive bivalves and revealed that the species could cause a shift in microbial communities when densities are high (Olden et al., 2013). Furthermore, $B$. chinensis is a facultative filter-feeder that has the potential to serve an important role in coupling benthic and pelagic food webs, in particular in lake ecosystems (Olden et al., 2013). The species can be abundant in optimal habitats, up to 38 individuals per $\mathrm{m}^{2}$ (Solomon et al., 2010; Chaine et al., 2012). Although densities in The Netherlands are lower (Soes et al., 2011, 2016), our observations confirm that $B$. chinensis expands its European range. Therefore, its ability to establish viable populations in cool to warm temperate climates (Jokinen, 1982; Karatayev et al., 2009) should justify the development of management strategies to prevent further spread in Belgium and elsewhere in Europe.

Acknowledgements. We would like to thank two anonymous reviewers for improving the manuscript.

\section{References}

Boets P, Brosens D, Lock K, et al. 2016. Alien macroinvertebrates in Flanders (Belgium). Aquat Invasions 11: 131-144.

Chaine NM, Allen CR, Fricke KA, et al. 2012. Population estimate of Chinese mystery snail (Bellamya chinensis) in a Nebraska reservoir. BioInvasions Rec 1: 283-287.

Harried B, Fischer K, Perez KE, Sandland GJ. 2015. Assessing infection patterns in Chinese mystery snails from Wisconsin, USA using field and laboratory approaches. Aquat Invasions 10: 169-175.

Havel JE. 2011. Survival of the exotic Chinese mystery snail (Cipangopaludina chinensis malleata) during air exposure and implications for overland dispersal by boats. Hydrobiologia 668: 195-202.

Johnson PT, Olden JD, Solomon CT, Vander Zanden MJ. 2009. Interactions among invaders: community and ecosystem effects of multiple invasive species in an experimental aquatic system. Oecologia 159: 161-170.

Jokinen EH. 1982. Cipangopaludina chinensis (Gastropoda, Viviparidae) in North America; review and update. The Nautilus 96: 89-95.

Karatayev AY, Burlakova LE, Karatayev VA, Padilla DK. 2009. Introduction, distribution, spread, and impacts of exotic freshwater gastropods in Texas. Hydrobiologia 619: 181-194.

McAlpine DF, Lepitzki DAW, Schueler FW, et al. 2016. Occurrence of the Chinese mystery snail, Cipangopaludina chinensis (Gray, 1834) (Mollusca: Viviparidae) in the Saint John River system, New Brunswick, with review of status in Atlantic Canada. BioInvasions Rec 5: 149-154.

McCann MJ. 2014. Population dynamics of the non-native freshwater gastropod, Cipangopaludina chinensis (Viviparidae): A capture-mark-recapture study. Hydrobiologia 730: 17-27.

Olden JD, Ray L, Mims MC, Horner-Devine MC. 2013. Filtration rates of the non-native Chinese mystery snail (Bellamya chinensis) and potential impacts on microbial communities. Limnetica 32: $107-120$

Smith DG. 2000. Notes on the taxonomy of introduced Bellamya (Gastropoda: Viviparidae) species in northeastern North America. The Nautilus 114: 31-37.

Soes DM, Majoor GD, Keulen SMA. 2011. Bellamya chinensis (Gray, 1834) (Gastropoda: Viviparidae), a new alien snail species for the European fauna. Aquat Invasions 6: 97-102.

Soes DM, Neckheim CM, Majoor GD, Keulen SMA. 2016. Current distribution of the Chinese mystery snail Bellamya chinensis (Gray, 1834) in The Netherlands. Spirula 406: 11-18.

Solomon CT, Olden JD, Johnson PTJ, Dillon RT, Vander Zanden MJ. 2010. Distribution and community-level effects of the Chinese mystery snail (Bellamya chinensis) in northern Wisconsin lakes. Biol Invasions 12: 1591-1605.

Stephen BJ, Allen C, Chaine NM, et al. 2013. Fecundity of the Chinese mystery snail in a Nebraska reservoir. J Freshw Ecol 28: $439-444$.

Cite this article as: Van den Neucker T, Schildermans T, Scheers K. 2017. The invasive Chinese mystery snail Bellamya chinensis (Gastropoda: Viviparidae) expands its European range to Belgium. Knowl. Manag. Aquat. Ecosyst., 418, 8. 